\title{
COCHLEAR IMPLANTATION IN PATIENTS WITH RENAL DYSFUNCTION
}

\author{
Sunil Goyal, Senthil Vadivu Arumugam, Suven Kalra, Sarankumar Thirugnanam, \\ Geetha Nair, Mohan Kameswaran
}

Department of Otorhinolaryngology, Madras ENT Research Foundation (P) Ltd., Chennai, India

Corresponding author: Sunil Goyal, Department of Otorhinolaryngology, Madras ENT Research Foundation (P) Ltd., Chennai, India, e-mail: drsunilgoyal@yahoo.co.in

\begin{abstract}
Background: Cochlear implantation is a safe surgery for restoration of hearing in severe to profound cochlear hearing loss candidates. Patients with congenital cochlear hearing loss may at times have renal anomalies. Renal dysfunction can contribute to sensorineural hearing loss, and it can affect cochlear implantation in a variety of ways, from minor intraoperative issues to major life-threatening complications.

Our study aimed to determine the prevalence of renal association encountered in cochlear implantees over a period of 15 years (Jan 2000-Dec 2014) at our centre; secondly to classify these renal associations, as this has an effect on management; and finally to suggest a protocol for perioperative management of cochlear implantees with renal comorbidity.

Material and methods: This is a retrospective study of 1000 consecutive patients who underwent cochlear implantation at the Madras ENT Research Foundation (Chennai) over the period Jan 2000-Dec 2014. All cochlear implantees with bilateral severe to profound cochlear hearing loss and associated renal associations were included. The data for our study were collected from nephrologist referral forms and medical records. The paper gives a nephrologist's perspective on perioperative care to be given during cochlear implantation. Relevant literature is reviewed.
\end{abstract}

Results: Overall prevalence of renal disease was 6 out of 1000 implantees $(0.6 \%)$ in our series. We classify the associated renal associations in cochlear implant candidates into 4 categories, and appropriate management for them is described.

Conclusions: A protocol for evaluating renal associations as they affect cochlear implantation has been designed, and the optimal management of these issues has been discussed.

Keywords: case management $\bullet$ cochlear implantation $\bullet$ renal insufficiency

\section{IMPLANTACIÓN COCLEAR EN PACIENTES CON TRASTORNOS RENALES}

\section{Resumen}

Introducción: La implantación coclear es un tratamiento seguro de restauración de la capacidad auditiva en los pacientes con hipoacusia coclear grave hasta profunda. Existen casos de hipoacusia congénita acompañada de trastornos renales que pueden causar hipoacusia perceptiva. Además, los trastornos renales influencian de diferentes formas el transcurso de la cirugía de implante coclear, comenzando por las decisiones intraoperatorias menos importantes hasta las complicaciones que ponen en peligro la vida del paciente. El objetivo de la investigación fue determinar la frecuencia con la que los trastornos renales afectaban las cirugías de implante coclear realizadas en pacientes de nuestro centro durante un periodo de 15 años (desde enero del año 2000 hasta diciembre del año 2015), así como clasificar las correlaciones observadas con respecto al tratamiento de los pacientes. Otro objetivo del estudio fue el desarrolo inicial de un plan de cuidados intraoperatorios de los pacientes implantados con trastornos renales.

Materiales y métodos: En el análisis retrospectivo se incluyeron 1000 pacientes con pérdida de audición bilateral de grado grave hasta profundo, implantados en el centro Madras ENT Research Foundation (Chennai) en el periodo desde enero del año 2000 hasta diciembre del año 2014. Los datos analizados provenían de las recomendaciones renales y las fichas clínicas. La presente publicación muestra los aspectos más importantes del cuidado intraoperatorio del paciente implantado desde el punto de vista renal, así como contiene la revisión bibliográfica correspondiente.

Resultados: En el grupo examinado los trastornos renales se presentaron en 6 por cada 1000 pacientes (0.6\%). Los trastornos renales coexistentes en los pacientes implantados se dividen en 4 categorías. Además, se ha descrito el modelo de cuidado de pacientes deseado. 
Conclusiones: Se ha creado un protocolo de valoración del impacto de los trastornos renales coexistentes sobre la cirugía de implante coclear. Además, se ha comentado el modelo óptimo de tratamiento de los pacientes con enfermedades de este tipo.

Palabras clave: tratamiento del paciente $\bullet$ implantación coclear $\bullet$ trastornos renales

\section{КОХЛЕАРНАЯ ИМПЛАНТАЦИЯ У ПАЦИЕНТОВ С НАРУШЕНИЯМИ ФУНКЦИЙ ПОЧЕК}

\section{Изложение}

Введение: Кохлеарная имплантация является безопасной операцией, возвращающей слух пациентам с тугоухостью тяжёлой и глубокой степени, вызванной повреждением структур внутреннего уха. Известны случаи, когда врождённой тугоухости сопутствуют нарушения функций почек, которые способствуют появлению нейросенсорной тугоухости. Кроме того, нарушения функций почек различным образом воздействуют на сам ход операции имплантации, начиная с менее существенных интраоперационных решений и заканчивая осложнениями, угрожающими жизни пациента.

Целью исследования было определение частоты влияния нарушений функций почек на операции кохлеарной имплантации, проводившиеся среди пациентов нашего центра в течение 15 лет (с января 2000 г. по декабрь 2015 г.), а также попытка классификации наблюдаемых связей относительно их влияния на ведение пациентов. Кроме того, исследование имело целью предварительную разработку протокола интраоперационного ухода во время операции имплантации за пациентами с имеющимися нарушениями функций почек.

Материал и метод: Ретроспективный анализ охватил 1000 пациентов, прошедших операцию кохлеарной имплантации в центре Madras ENT Research Foundation (Ченнаи) в период с января 2000 г. по декабрь 2014 г., с двусторонней потерей слуха тяжёлой и глубокой степени, и нарушениями функций почек. Проанализированные данные были получены из нефрологических рекомендаций и карт больного. Настоящая публикация представляет самые важные аспекты интраоперационного ухода за пациентом при операции имплантации в нефрологической перспективе и содержит обзор соответствующей литературы предмета.

Результаты: В исследуемой группе нарушения функций почек имели место у 6 пациентов из 1000 (0,6\%). Сосуществующие у оперированных пациентов нарушения функций почек были разделены на 4 категории. Кроме того, была представлена желательная модель ухода за пациентом.

Выводы: Был создан протокол, оценивающий сосуществующие нарушения функций почек с точки зрения их влияния на операцию кохлеарной имплантации. Кроме того, была рассмотрена оптимальная модель ведения пациентов с болезнями данного типа.

Ключевые слова: ведение пациента • кохлеарная имплантация • нарушения функций почек

\section{IMPLANTACJA ŚLIMAKOWA U PACJENTÓW Z ZABURZENIAMI CZYNNOŚCI NEREK}

\section{Streszczenie}

Wprowadzenie: Implantacja ślimakowa jest bezpiecznym zabiegiem przywracającym słuch pacjentom z niedosłuchem ślimakowym stopnia od znacznego do głębokiego. Istnieją przypadki, w których wrodzonemu niedosłuchowi towarzyszą zaburzenia czynności nerek, które przyczyniają się do powstania niedosłuchu odbiorczego. Ponadto, zaburzenia czynności nerek wpływają w różnorodny sposób na sam przebieg zabiegu implantacji, począwszy od mniej istotnych decyzji śródoperacyjnych aż po komplikacje zagrażające życiu pacjenta.

Celem badania było ustalenie częstości wpływu zaburzeń czynności nerek na zabieg implantacji ślimakowej, przeprowadzony wśród pacjentów naszego ośrodka w okresie 15 lat (od stycznia 2000r. do grudnia 2015r.) oraz sklasyfikowanie obserwowanych powiązań względem ich wpływu na prowadzenie pacjentów. Ponadto, badanie miało na celu wstępne opracowanie protokołu opieki śródoperacyjnej nad pacjentami implantowanymi z występującymi zaburzeniami czynności nerek.

Materiał i metoda: Do analizy retrospektywnej włączono 1000 pacjentów implantowanych w ośrodku Madras ENT Research Foundation (Chennai) w okresie od stycznia 2000 do grudnia 2014, z obustronnym ubytkiem słuchu stopnia od znacznego do głębokiego i zaburzeniami czynności nerek. Dane poddane analizie pochodziły z zaleceń nefrologicznych oraz kart pacjenta. 
Niniejsza publikacja przedstawia najważniejsze aspekty śródoperacyjnej opieki nad pacjentem implantowanym z perspektywy nefrologicznej oraz zawiera przegląd odpowiedniej literatury przedmiotu.

Wyniki: W badanej grupie zaburzenia czynności nerek występowały u 6 na 1000 pacjentów (0,6\%). Współwystępujące u pacjentów implantowanych zaburzenia czynności nerek przyporządkowano do 4 kategorii. Ponadto, opisano pożądany model opieki nad pacjentem.

Wnioski: Stworzono protokół oceniający współwystępujące zaburzenia czynności nerek pod względem ich wpływu na zabieg implantacji ślimakowej. Ponadto, omówiono optymalny model prowadzenia pacjentów ze schorzeniami tego typu.

Słowa kluczowe: prowadzenie pacjenta • implantacja ślimakowa • zaburzenia czynności nerek

\section{Introduction}

Cochlear implantation (CI) has revolutionized the treatment of patients with severe to profound cochlear hearing loss. It is a safe surgery for restoration of hearing in such patients. At the same time, patients with congenital cochlear hearing loss may have associated renal anomalies [1-3], and renal dysfunction can also cause sensorineural hearing loss (SNHL) [4-6]. Renal dysfunction can affect cochlear implantation in a variety of ways, from minor intraoperative issues to major life-threatening complications $[4,7]$. Issues related to perioperative care need to be addressed by a team approach. Hence there is a need to develop a safe protocol which addresses perioperative issues in these patients.

\section{Aims and objectives}

Our study had three aims: 1) to determine the prevalence of renal association encountered in cochlear implantees over a period of 15 years (Jan 2000 - Dec 2014) at our centre; 2) to classify these renal associations, as they have an influence on management; and 3) formulate a protocol for perioperative management of cochlear implantees with renal comorbidity.

\section{Study methodology}

A retrospective study of 1000 consecutive patients who underwent cochlear implantation at Madras ENT Research Foundation hospital, Chennai, over a period of 15 years (Jan 2000-Dec 2014) formed the basis of our study. All cochlear implantees with bilateral severe to profound cochlear hearing loss and associated renal associations at our institution were included in the study. The data for our study were collected from nephrologist referral forms and the Medical Records department. A literature review was done using searches of Pub Med and Google using the key words cochlear implantation, renal anomalies, hearing loss, pediatric, and acute kidney injury.

As per our institute protocol, all likely implantees were administered a detailed questionnaire (see Appendix 1) to collect detailed information on their medical history, including anything suggestive of renal involvement at the time of first visit to the hospital. Following a basic medical examination, investigations such as complete blood count (CBC), urine routine examination, TORCHS serology, chest radiograph, electrocardiogram (ECG), blood urea nitrogen (BUN), serum creatinine, blood sugar level, liver function test (LFT), and thyroid function test (TFT) were done. A battery of comprehensive evaluation, opinions of pediatrician, ophthalmologist, cardiologist, clinical psychologist, and occupational therapist were next sought for childhood onset hearing loss.

In cases with suspected renal involvement, apart from the routine investigations, patients were further subjected to specific preoperative investigation such as serum electrolytes, creatinine clearance, coagulation profile, glycosylated hemoglobin (HbA1c), and ultrasonography of kidneyureter-bladder (KUB). In all dialysis and renal transplant patients, HbsAg, HCV, and HIV tests were undertaken. Cardiovascular status was assessed with echocardiography.

From the data collected, firstly the prevalence of renal association among cochlear implantees was determined. Second, a classification was suggested based on the experience of our surgical team (comprising surgeon, anesthesiologist, and nephrologist) and a review of literature, which could be used in the management of such cases. Finally, a tentative management protocol for the perioperative management of such cases was formulated, based on the literature review and the experience of our surgical team in this area (6 cases of cochlear implantation with renal anomalies or dysfunction out of a total of 1000 implants done at our centre over a period of 15 years). This paper reflects the need for a team approach, giving a nephrologist's perspective on perioperative care to be given during cochlear implantation.

\section{Observations and results}

Renal disease was identified and confirmed in 6 out of 1000 consecutive cochlear implantees, giving a prevalence rate of $0.6 \%$ at our centre. All 6 patients had bilateral profound cochlear hearing loss. The details of the 6 patients are given in Table 1. All 6 patients underwent cochlear implantation by the most senior surgeon at our centre, in order to reduce the duration of surgery. Immunosuppressive drugs and antihypertensive medication were continued in the intraoperative period as advised by the nephrologist.

All 4 post-renal transplant patients were detected to have mildly deranged renal parameters and were on immunosuppressive drugs. High-risk consent was given by all post-renal transplantation patients for undergoing cochlear implantation.

Based on our data and the review of the literature, the patients with severe cochlear hearing loss with renal associations were classified into four severity grades as shown in Table 2. 
Table 1. The details of the six patients mentioned

\begin{tabular}{|c|c|c|c|c|c|c|c|}
\hline Sr. No. & Age/Sex & Onset & $\begin{array}{l}\text { Duration of } \\
\text { hearing loss }\end{array}$ & Etiology & Renal association & $\begin{array}{l}\text { Immuno } \\
\text { suppression }\end{array}$ & Date of $\mathrm{Cl}$ \\
\hline 1 & $\begin{array}{l}2 \text { years/ } \\
\text { Male }\end{array}$ & Pre lingual & 2 years & $\begin{array}{l}\text { Congenital non } \\
\text { syndromic }\end{array}$ & $\begin{array}{l}\text { Medullary nephro } \\
\text { calcinosis + diuretics }\end{array}$ & No & $\begin{array}{l}25 \text { Sep } \\
2004\end{array}$ \\
\hline 2 & $\begin{array}{l}3 \text { years/ } \\
\text { Male }\end{array}$ & Pre lingual & 3 years & BOR & $\begin{array}{l}\text { Single kidney } \\
\text { No treatment }\end{array}$ & No & $\begin{array}{l}19 \text { Sep } \\
2005\end{array}$ \\
\hline 3 & $\begin{array}{l}24 \text { years/ } \\
\text { Male }\end{array}$ & Post lingual & 11 years & Alport's syndrome & $\begin{array}{l}\text { Renal failure }+ \\
\text { post renal tranplant } \\
(1996)\end{array}$ & Yes & $\begin{array}{l}10 \text { Jan } \\
2006\end{array}$ \\
\hline 4 & $\begin{array}{l}21 \text { years/ } \\
\text { Female }\end{array}$ & Post lingual & 3 years & $\begin{array}{l}\text { Gentamicin } \\
\text { ototoxicty }\end{array}$ & $\begin{array}{l}\text { Renal failure }+ \text { post } \\
\text { renal tranplant }(2005)\end{array}$ & Yes & $\begin{array}{l}13 \text { Jan } \\
2008\end{array}$ \\
\hline 5 & $\begin{array}{l}30 \text { years/ } \\
\text { Male }\end{array}$ & Post lingual & 27 years & $\begin{array}{l}\text { Malaria } \\
\text { Post renal failure }\end{array}$ & $\begin{array}{l}\text { Renal failure + post } \\
\text { renal tranplant (2009) }\end{array}$ & Yes & $\begin{array}{l}4 \mathrm{Apr} \\
2012\end{array}$ \\
\hline 6 & $\begin{array}{l}51 \text { years/ } \\
\text { Male }\end{array}$ & Post lingual & 5 years & $\begin{array}{l}\text { Hypertension } \\
\text { Post renal failure }\end{array}$ & $\begin{array}{l}\text { Renal failure }+ \text { post } \\
\text { renal tranplant (2009) }\end{array}$ & Yes & $\begin{array}{l}16 \text { Jun } \\
2013\end{array}$ \\
\hline
\end{tabular}

Table 2. Suggested classification for severe cochlear hearing loss with renal association

\begin{tabular}{lc}
\hline \multicolumn{1}{c}{ Severity grading (grades 1-4) } & Number of patients in our series \\
\hline 1. Renal association not requiring treatment & 1 \\
\hline 2. Renal association with chronic kidney disease on diuretics not requiring dialysis & 1 \\
\hline 3. Renal association with chronic kidney disease on dialysis & 0 \\
\hline 4. Renal association with chronic kidney disease post renal transplant & 4 \\
\hline
\end{tabular}

At the start of surgery, antibiotic injection of cefoperazone $(20 \mathrm{mg} / \mathrm{kg})$ followed by oral cefuroxime axetil $(10 \mathrm{mg} / \mathrm{kg})$ was given, avoiding direct nephrotoxic antibiotics such as aminoglycosides. Intraoperatively, all patients were catheterized, starting with a central line for monitoring. In hypertensive patients, blood pressure was controlled with a nitroglycerine drip. Angiotensin-converting enzyme inhibitors (ACEIs) and succinyl choline were avoided because of the risk of hyperkalemia.

Suggested work-up protocol for cochlear implantees with renal associations is given in Table 3.

Fluorinated compounds like enflurane and sevoflurane are avoided because of the potential of forming nephrotoxic compounds. Induction of anesthesia was done with injection of propofol (1-2 mg/kg) and injection of fentanyl and maintained with propofol infusion $(4-10 \mathrm{mg} /$ $\mathrm{kg} / \mathrm{h})$. Atracurium $(0.5 \mathrm{mg} / \mathrm{kg})$ was given as a muscle relaxant. Vecuronium and pancuronium are avoided because of the chances of prolonged neuromuscular block in renal dysfunction. For reversal, injection of myopyrolate (neostigmine $0.05-0.08 \mathrm{mg} / \mathrm{kg}+$ glycopyrolate $10 \mu \mathrm{g} / \mathrm{kg}$ ) was given. NSAIDS are avoided because of their nephrotoxic potential. Analgesia was provided with injection or oral paracetamol or tramadol for 2-3 days only.

Strict monitoring of vital parameters was done during the surgery. ABG was done to identify any acidosis and electrolyte abnormality and managed accordingly prior to extubation. Injection of hydrocortisone was given perioperatively for patients on immunosuppressive therapy. In the postoperative period, fluid intake was monitored with an intake/output chart. Tablets of cefuroxime axetil (10 mg/ $\mathrm{kg} 12$ hourly) were started once the patient could start taking by mouth until sutures were removed on the tenth postoperative day.

None of the patients had any renal or non-renal complications. However, our results should not be extrapolated to all cases of cochlear implantation and all precautions should be taken to prevent and manage likely complications. Routine switch-on and rehabilitation protocols were followed with good outcome in all our patients. At discharge, all patient were advised to be under the follow-up of their nephrologist. Since the number of implantees with renal disease was only 6 , no statistical tests were carried out.

\section{Discussion}

Although CI is a safe surgery and has revolutionized the treatment of patients with severe SNHL, the surgery can be complex and require specific measures to be taken to reduce complications when SNHL co-exist with renal dysfunction.

\section{Prevalence}

Renal pathology was identified and confirmed in 6 out of 1000 consecutive cochlear implantees, giving a prevalence rate of $0.6 \%$ at our centre. All six patients had bilateral profound cochlear hearing loss. We could not find any relevant literature indicating the prevalence of renal associations in cochlear implantees. 


\section{Ototoxicity}

Ototoxicity is a trait shared by aminoglycoside and macrolide antibiotics, loop diuretics (ethacrynic acid and furosemide), platinum-based chemotherapeutic agents, NSAIDs, and antimalarial medications. Because their benefits in combating certain life-threatening diseases often outweigh the risks, the use of these ototoxic drugs simply cannot be avoided. These agents also have substantial nephrotoxic effects. Pathogenesis appears to involve ironinduced formation of free radicals. Analogous effects of aminoglycosides on inner and outer hair cells have been observed $[3,13]$. Our case was a 21 year old female who had developed renal failure and sudden SNHL following injection of gentamicin 3 years back. She underwent renal transplantation in 2005.

\section{Post renal failure and renal transplantation}

CKD may result in SNHL, most likely due to uremia [5], electrolyte imbalance [14], or administration of ototoxic drugs [15]. Another report [16] has mentioned that renal transplantation might improve hearing function at first, but in the long term hearing deteriorates. The underlying cause is still unclear, but it might be due to vascular changes in the inner ear due to hyperlipidemia induced by steroid therapy, treatment with ototoxic drugs, or recurrence of renal disease [17]. Since SNHL is a common complication of CKD, CI is performed after renal transplantation. Immunosuppressive drugs can be continued perioperatively. Perioperative prophylactic antibiotic therapy has been shown to decrease postoperative complication rates [1820]. In our study, one of the patients developed CKD following complicated malaria, while another patient was a diagnosed case of CKD due to hypertention. Both patients reported to us, post renal transplantation, with SNHL. We had a total of 4 patients with CKD post renal transplantation with profound SNHL. All 4 patients were on immunosuppressive drugs and had mildly deranged renal parameters.

\section{Others}

On review of the literature we came across certain other disease conditions which can have renal associations along with bilateral SNHL, and such patients are likely to be candidates for CI surgery. These conditions include distal renal tubular acidosis, MYH-9 related disease (May Heggin anomaly, Sebastian syndrome, Fechtner syndrome, and Epstein syndrome), and Towne Brokes syndrome [6,21,22]. It is recommended that all such patients should be investigated for hearing impairment and managed accordingly.

\section{Need for classification and proposed classification}

Renal dysfunction may influence cochlear implantation in a variety of ways from minor intraoperative issues to major life-threatening complications. Issues related to perioperative care need to be addressed with a team approach. There is therefore a need to develop a safe protocol which will address the perioperative issues related to these patients. We have suggested a practical classification for the various renal associations into 4 groups - Table 2 and Table 3 - which are intended as a guide for the ENT surgeon in the perioperative management of these patients.
We had only one patient in each of the first and second groups. We did not operate on any patients with CKD on dialysis because of the increased risk of complications. The remaining 4 patients which we operated upon belonged to the fourth group - i.e. CKD post renal transplantation. Surgery should be delayed in these patients for at least 6 months after renal transplantation $[18,19]$. The minimum gap between renal transplantation and cochlear implantation was 3 years in our series of patients.

\section{Management}

\section{Complications due to abnormal renal function}

The kidney has both excretory and synthesizing functions. Impairment of the excretory function results in an elevation in levels of BUN, creatinine, and various protein metabolic products. Impairment in the synthesizing function results in a decrease in the production of erythropoietin (causing anemia), active vitamin $\mathrm{D}_{3}$ (causing hypocalcemia, hyperphosphatemia, and renal osteodystrophy); reduction of acid, potassium, salt, and water excretion (causing acidosis, hyperkalemia, hypertension, and edema); and in platelet dysfunction (promoting bleeding). Hence CKD can be associated with increased surgical morbidity, the most important of which includes AKI, hyperkalemia, cardiac complications, and infection [23]. These four likely complications must be identified and corrected perioperatively, as follows.

$A K I$. AKI is defined when any of the following three criteria are met: 1) an increase in serum creatinine by $50 \%$ in 7 days; 2) an increase in serum creatinine $>0.3 \mathrm{mg} / \mathrm{dL}$ in 48 hours; or 3) oliguria [32,24]. AKI occurs in $1-5 \%$ of all hospitalized patients, and in the perioperative period has serious implications associated with unacceptable high mortality (1\% in general surgical patients and as high as $17 \%$ in cardiac surgery patients), morbidity, and a more complicated hospital course and cost [7,25-27].

Prerenal azotemia is characterized by a decrease in glomerular filtration rate (GFR) due to a decrease in renal perfusion pressure without damage to the renal parenchyma. Causes includes hypovolemia, decreased cardiac output states, decreased vascular resistance (peripheral vasodilation), and renal vasoconstriction (from vasoconstrictive medications or conditions such as hypercalcemia). In general, therapy aimed at rapidly restoring renal perfusion will promptly improve renal function. However, prolonged or profound prerenal azotemia can result in ischemic damage to the kidney and thus there is spectrum from prerenal azotemia to ischemic AKI. Intrinsic AKI can be due to damage to any of the four major structures of the kidney (tubules, glomeruli, interstitium, and intrarenal blood vessels) [28]. The diagnosis of AKI increases the risk of mortality 5.5-6.5 fold compared to a similar patient without AKI.

Contrast-induced nephropathy is a serious complication with unfavourable prognosis. Where its use is unavoidable, the minimum possible dose of isomolor (less toxic) contrast should be given combined with hydration, oral $\mathrm{N}$-acetylcysteine, and sodium bicarbonate $[28,29]$. None of our patients required intravenous contrast imaging. 
Hyperkalemia. Hyperkalaemia is the most frequent lifethreatening complication of CKD. Severe hyperkalaemia ( $>8 \mathrm{mmol} / \mathrm{L}$ ) can cause cardiac arrest and death with very few warning symptoms. In stage $4-5 \mathrm{CKD}$, hyperkalaemia may be an indication for starting renal replacement therapy (RRT). Drug treatment with ACEIs and angiotensin receptor blockers (ARBs) can contribute to hyperkalaemia, which can also be exacerbated by treatment with spironolactone (indicated in the treatment of heart failure), beta blockers, and NSAIDs. Severe hypovolaemia, which may complicate the treatment of heart failure with high dose diuretics, may also cause hyperkalaemia in the presence of CKD.

Cardiac complications. Cardiovascular complications are more likely in CKD patients and are the most common cause of death in this group of patients [30]. Hypertension may be secondary to renal disease or primarily cause renal disease. Hence control of blood pressure by blocking of the renin angiotensin system, such as with ACEIs and $\mathrm{ARBs}$, is important in preserving residual function in renal disease and has prognostic benefit in proteinuric renal disease [31,32].

Infection and bleeding. Potential risk factors for infection among patients with CKD includes advanced age, coexisting illnesses, hypoalbuminemia, immunosuppressive therapy, nephrotic syndrome, uremia, anemia, and malnutrition. Additional potential risk factors for infection include vascular access used for dialysis, the dialysis procedure itself, and iron overload. In fact, ESRD may be considered a state of acquired immunodeficiency. Thus strategies to prevent infections (e.g. vaccination, antibiotics) are of paramount importance in CKD patients. Compared to healthy individuals, patients with advanced CKD seem to have reduced responsiveness to vaccination, including pneumococcal vaccination [33]. CKD patients have a bleeding tendency due to platelet dysfunction.

\section{Preoperative evaluation}

Patients with renal associations are often asymptomatic and thus recognition of these cases depends on the identifying socio-demographic factors (obesity, smoking, alcohol) and common associated diseases, syndromic and non-syndromic associations (e.g. diabetes, hypertension, and peripheral vascular disease), and laboratory testing. These risk factors need to be identified.

In suspected cases, investigations should aim to diagnose renal associations after a thorough history and clinical examination. They should try to establish the level of renal function impairment at the same time as investigations done for CI. All these patients will need optimization of their renal function prior to surgery. A nephrologist's opinion and expert management are part of a team approach to better patient care. Patients can be divided into the four categories of Table 2, and work-up procedures are given in Table 3.

Risk factors for AKI include age $>56$ years, male, acute congestive heart failure, ascitis, hypertension, emergency surgery, renal insufficiency, diabetes mellitus, and preoperative liver dysfunction $[7,26]$. Patients with 3 or more risk factors had an AKI incidence of 4.3\% and such patients should be considered high risk [7]. High risk consent was taken in all our post renal transplant patients.

General anesthesia should be avoided in patients with CKD who have a serum potassium level above $5.5 \mathrm{mEq} / \mathrm{L}$ [34]. Management of hyperkalemia includes: antagonize the effects of hyperkalemia at the cellular level (membrane stabilization with injection of calcium); promoting the influx of potassium into cells (insulin, beta 2 agonist, sodium bicarbonate); and removing potassium from the body (RRT) [35]. All our patients had normal serum potassium level perioperatively.

Cardiac risk factors include age $>50$ years, history of angina, diabetes mellitus, or congestive heart failure, and an abnormal ECG [34]. Preoperative serum creatinine $>2 \mathrm{mg} / \mathrm{d}$ has been found to be an independent predictor of cardiac complications both in cardiac and non-cardiac surgery [36]. None of our patients had serum creatinine $>2 \mathrm{mg} / \mathrm{d}$.

Patients with CKD and hypertension should continue antihypertensive drug therapy throughout the perioperative period. Oral agents that cannot be given intravenously, such as clonidine may be replaced with a transdermal patch 2 to 3 days before surgery or with an intravenously administered agent. Diuretics should be discontinued 2 to 3 days before surgery to avoid intraoperative hypotension which may worsen renal function (unless they are being used for congestive heart failure or nephrotic syndrome). Abrupt withdrawal of NSAIDs, antihistamines, and decongestants should be avoided as it may cause rebound hypertension. Hypoglycemia may also cause hypertension as a result of catecholamine release for mobilization of glycogen stores. This most commonly occurs in patients with diabetes mellitus who are kept on nil peroral status for a prolonged period before surgery. Inadvertent hypoglycemia can be avoided with continuous administration of a low dose dextrose infusion [35]. In our series of patients, antihypertensives were started preoperatively after seeking the opinion of the nephrologist. None of our patients were diabetic.

To minimize uremic complications, patients with ESRD should undergo dialysis on the day before surgery. Antiplatelet agents should not be given within 72 hours before surgery in patients with ESRD or uremic CKD. In addition, some agents, like NSAIDs and chlordiazepoxide, have minor antiplatelet effects and may increase the risk of intraoperative bleeding and should be avoided [34]. We did not operate on any of the patients with ESRD or uremic CKD. None of our patients required dialysis.

In patients with $\mathrm{CKD}$, correcting severe anemia may help to avoid complications from perioperative blood loss. In elective surgery, erythropoietin may be administered along with oral iron supplements to raise the hematocrit to the upper acceptable value. Treatment should be initiated several weeks before surgery [34]. None of our patients had severe anaemia. All anaemic patients were started on oral iron supplementation 1-3 months prior to surgery. To reduce intraoperative blood loss and infection, all patients were operated on by the most senior surgeon at our 
institute. To reduce the chance of infection all our patients were immunized.

\section{Intraoperative management}

Maintenance of normal renal perfusion is perhaps the most important prophylactic measure, with $80 \%$ of patients experiencing postoperative AKI having an episode of hemodynamic instability in the perioperative period. A metaanalysis demonstrated that AKI is significantly reduced by perioperative hemodynamic optimization [37]. Strategies to maintain renal blood flow adopted by the anesthesiologist in our team included intravenous hydration, tight control of blood pressure (nitroglycerine drip), and administration of vasoactive substances. Intraoperative urine output and central venous pressure was also monitored closely.

Nephrotoxicity results from a variety of exogenous compounds (e.g. aminoglycosides, amphotericin B, cisplatinum, NSAIDs, radiocontrast media) and endogenous compounds (e.g. hemoglobin and myoglobin) [38]. All likely potential nephrotoxicity drugs were identified and either the drug was stopped or its dose or dosing interval adjusted for the level of renal function. At our institute, injection of cefeperazone was given during the perioperative period, followed by oral cefuroxime to reduce infection, because of its safety profile in terms of nephrotoxicity.

The risk of AKI is three times higher in NSAID users than in non-NSAID users [39]. Short term use of NSAIDs is generally safe in patients who are well hydrated, who have good renal function, and who do not have heart failure, diabetes, or hypertension [40]. We generally avoided NSAIDs in the six reported patients.

Although opioids have no direct toxic effects on the kidney, their antidiuretic effect may lead to urinary retention [32]. With the exception of methadone, the majority of opioids undergo hepatic biotransformation and renal excretion as the primary route of elimination. The significant renal retention of active or toxic metabolites of commonly used opioids can occur among advanced CKD patients and lead to profound central nervous system and respiratory depression and hypotension. In addition, myoclonus and seizures are well-recognized serious neurological complications with the use of high doses of morphine, hydromorphone, meperidine (pethidine), fentanyl, and diamorphine [41]. Tramadol is generally preferred for moderate pain in CKD patients because it is not directly nephrotoxic. Nonetheless, its systemic elimination is reduced with advanced CKD and it may precipitate serotonin syndrome in patients taking selective serotonin reuptake inhibitors [41]. Uraemia is associated with a lowered seizure threshold, and tramadol may be epileptogenic in these circumstances [42]. The maximum dose of tramadol prescribed to advanced CKD patients should not exceed 50 mg orally twice a day [41]. Dose reduction for most opioids in patients with reduced renal function must therefore be considered to avoid drug accumulation and associated complications $[32,41]$. In our series of patients we used paracetamol or tramadol for analgesia again because of their safety profiles.
Common medications known to cause hyperkalemia include ACEIs, ARBs, penicillin G, trimethoprim, spironolactone, succinylcholine, and heparin [35]. All such medications were avoided in the perioperative period.

Halothane, enflurane, isoflurane, and sevoflurane are all known to react with $\mathrm{CO}_{2}$ absorbants and produce haloalkenes, which are toxic to kidneys. Sevoflurane reacts with $\mathrm{CO}_{2}$ absorbants to form a special haloalkene, compound A. However, low flow sevoflurane anesthesia seems to be as safe as low flow anesthesia with other inhalation agents [43]. In renal failure patients, thiopental has reduced plasma protein binding, exposing the brain to a higher freedrug concentration, necessitating dose reduction. However, the pharmacokinetics of propofol are stable, even in established renal failure and can be used safely [32]. In our case series we used injection propofol for induction of anesthesia because of its safety profile.

In CKD patients, a larger initial dose is required to produce neuromuscular block. However, the maintenance dose needs to be reduced, with the exception of atracurium and cisatracurium. Long-acting neuromuscular blocking agents (NMBA) and drugs eliminated by urinary excretion (D-tubocurarine and pancuronium) should be avoided to prevent postoperative residual curarization (PORC). Although vecuronium undergoes predominantly biliary excretion, with constant infusion or repeated bolus dose a prolonged neuromuscular block occurs as the drug accumulates. Atracurium undergoes Hofmann degradation and metabolism by nonspecific esterases and is not dependent upon liver or kidney for its elimination [32]. In our case series we used injection of atracurium as muscle relaxant because of its safety profile.

Patients with CKD often have anemia. Moreover, CI is more commonly done in the pediatric age group in which, because of low total blood volume, a small amount of blood loss is significant. Given these concerns, transfusion may seem necessary in some circumstances. A possible downside to blood product transfusion is antibody formation, which may decrease a patient's future chances of successful renal transplantation. In addition, intraoperative infusion of blood may cause hyperkalemia as a result of cellular lysis [37]. To avoid these problems, all patients were operated on by the most senior surgeon with meticulous care to hemostasis. None of our patients required perioperative blood transfusion.

\section{Postoperative management}

During the postoperative period, fluid intake was monitored with an intake/output chart and hourly urine output recorded for first 48 hours. Nephrotoxic antibiotics and analgesics were avoided. Serum creatinine levels were monitored for the first 48 hours post-operatively to identify and manage AKI. For 72 hours postoperative, cardiac monitoring was done with ECG and troponin T 8-hourly. Tablets of cefuroxime axetil ( $10 \mathrm{mg} / \mathrm{kg} 12$ hourly) were started once the patient could accept them by mouth and until sutures were removed on the tenth postoperative day. For post renal transplantation, oral or intravenous immunosuppression as appropriate is required [33]. Injection of hydrocortisone was given perioperatively for patients on 


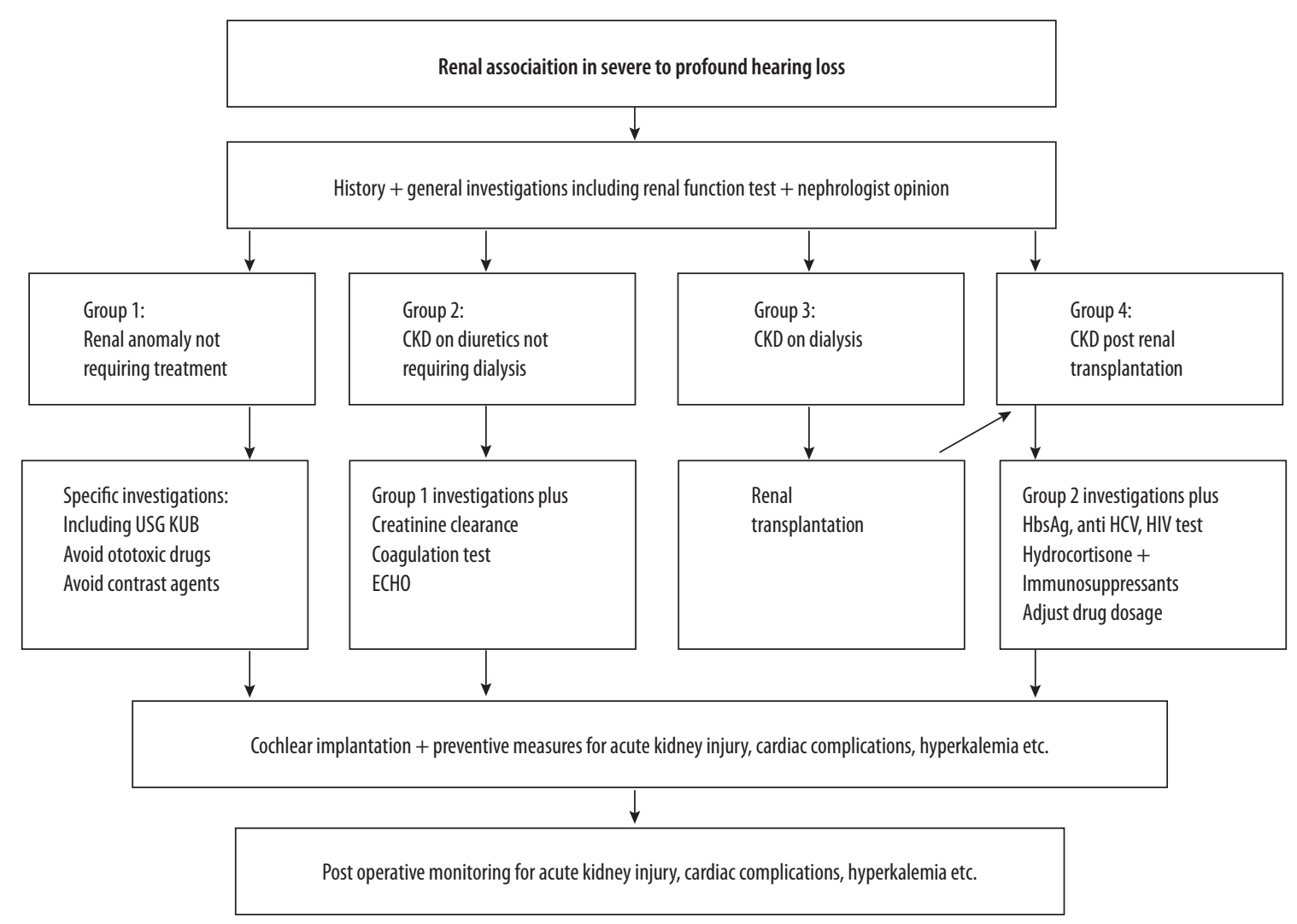

Figure 1. Flow chart of a management protocol for cochlear implantation in patients with renal associations

immunosuppressive therapy followed by oral immunosuppressants in all our four post renal transplant patients.

In our study none of the implantees had any significant renal or non-renal complications. However our results cannot be generalized, firstly because of the small number (only six cases) of associated renal disease among implantees and, secondly, we decided not to operate on any of the patients with CKD on dialysis which is more likely to develop complications. Hence we suggest that for all cases of cochlear implantations with renal associations all precautions should be taken to prevent and manage likely complications.

\section{Management protocol}

Suggested management protocol for cochlear implantation in patients with renal associations is presented in Figure 1 (a flow chart) and Table 3.

\section{Conclusions}

Although CI is a safe surgery, the presence of renal comorbidity can be associated with increased perioperative mortality, even when adjusted for other variables such as hypertension or diabetes. However, there is a lack of awareness among otolaryngologists about CKD and its associated risks. AKI is frequently underdiagnosed during acute hospital care and surgery, and is often not included in the clinical decision-making process. Hence, it is pertinent to identify these cases, classify them based on the associated risk, and take appropriate interventions during the preoperative evaluation phase. Non-emergency procedures should be postponed until the causes of preoperative renal dysfunction are evaluated and appropriate treatment initiated, the goal being to optimise renal function as much as possible before anesthesia and surgery. The ultimate goal of preoperative evaluation is to reduce the chance of adverse perioperative renal events.

This paper, based on our experience and a review of literature, tries to provide an insight into the various issues associated with renal dysfunction in CI surgery. It also provides cochlear implant surgeons with a perspective for categorizing renal problems and planning their management. Such a protocol might assist cochlear implant surgeons worldwide and provide a basis for future improvements. 
Appendix 1. Questionnaire used to collect details of medical histories

1. Name:

2. Address:

3. H/O Consanguineous marriage:

4. Antenatal history:

5. Birth history:

6. Mode of delivery:

7. APGAR Score:

8. Post natal NICU admission:

9. $\mathrm{H} / \mathrm{O}$ any syndromic association:

10. H/O prolonged hospitalisation:

11. $\mathrm{H} / \mathrm{O}$ blood transfusion:

12. H/O intake of ototoxic drugs:

13. H/O dialysis:

14. $\mathrm{H} / \mathrm{O}$ renal transplantation:

15. H/O convulsions:

16. H/O suggestive of cardiac diseases:

17. H/O suggestive of thyroid diseases:

18. H/O visual disturbances:

19. H/O delayed mile stones:

20. H/O exanthematous fever:

24. Other past medical history if any:

25. Past H/O surgery:

26. Family $\mathrm{H} / \mathrm{O}$ medical illness:

27. Family H/O congenital deafness:

28. Immunized for age:

29. Treatment history if any:
Serial number:

Yes / No (if Yes degree)

Infection / Medication (if Yes, details

Full term / Pre term

Via naturalis / Caesarean section

Birth weight

Yes / No (if Yes, details

Yes / No

Yes / No

Yes / No

Yes / No

Yes / No

Yes / No

Yes / No

Yes / No (if Yes, details

Yes / No (if Yes, details

Yes / No (if Yes, details

Yes / No (if Yes, details

Yes / No (if Yes, details

Yes / No

Yes / No (if Yes, details

Yes / No

Yes / No

\section{References:}

1. Soriano JR. Branchio-oto-renal syndrome. J Nephrol, 2003; 16(4): 603-5.

2. Kashtan CE. Alport syndrome: An inherited disorder of renal, ocular, and cochlear basement membranes. Medicine, 1999; 78(5): 338-60.

3. Humes HD. Insights into ototoxicity. Analogies to nephrotoxicity. Ann NY Acad Sci, 1999; 884: 15-18.

4. Meena RS, Aseri Y, Singh B, Verma P. Hearing loss in patients of chronic renal failure: A study of 100 cases. Indian J Otolaryngol Head Neck Surg, 2012; 64(4): 356-59.

5. Vilayur E, Gopinath B, Harris DC, Burlutsky G, McMahon $\mathrm{CM}$, Mitchell P. The association between reduced GFR and hearing loss: A cross-sectional population-based study. Am J Kidney Dis, 2010; 56(4): 661-69.

6. Sharifian M, Esfandiar N, Mazaheri S, Kariminejad A, Mohkam $\mathrm{M}$, Dalirani R et al. Distal renal tubular acidosis and its relationship with hearing loss in children: preliminary report. Iran J Kidney Dis, 2010; 4(3): 202.

7. Kheterpal S, Tremper KK, Englesbe MJ, O’Reilly M, Shanks AM, Fetterman DM et al. Predictors of postoperative acute renal failure after noncardiac surgery in patients with previously normal renal function. Anesthesiology, 2007; 107(6): 892-902.

8. Sayer JA, Georgina C, Simmons NL. Nephrocalcinosis: Molecular insights into calcium precipitation within the kidney. Clin Sci, 2004; 106(6): 549-61.

9. Fraser F, Sproule J, Halal F, Optiz JM. Frequency of the branchio-oto-renal (BOR) syndrome in children with profound hearing loss. Am J Med Geneti, 1980; 7(3): 341-49.

10. Gorlin RJ, Toriello HV, Cohen MM. Hereditary hearing loss and its syndromes: Oxford University Press, USA, 1995.
11. König R, Fuchs S, Dukiet C. Branchio-oto-renal (BOR) syndrome: Variable expressivity in a five-generation pedigree. Eur J Pediatr, 1994; 153(6): 446-50.

12. Colville D, Savige J. A review of the ocular manifestations. Ophthalmic Genet, 1997; 18(4): 161-73.

13. Yorgason JG, Fayad JN, Kalinec F. Understanding drug ototoxicity: Molecular insights for prevention and clinical management. Expert Opin Drug Saf, 2006; 5(3): 383-99.

14. Gatland D, Tucker B, Chalstrey S, Keene M, Baker L. Hearing loss in chronic renal failure-hearing threshold changes following haemodialysis. J R Soc Med, 1991; 84(10): 587-89.

15. Mancini M, Strologo LD, Bianchi P, Tieri L, Rizzoni G. Sensorineural hearing loss in patients reaching chronic renal failure in childhood. Pediatr Nephrol, 1996; 10(1): 38-40.

16. Mitschke H, Schmit P, Zazgornik J, Kopsa H, Pils P. Effect of renal transplantation on uremic deafness: A long-term study. Audiology, 1977; 16(6): 530-34.

17. Antonelli A, Bonfioli F, Garrubba V, Ghisellini M, Lamoretti M, Nicolai $\mathrm{P}$ et al. Audiological findings in elderly patients with chronic renal failure. Acta Oto-Laryngologica Suppl, 1990; 476: 54-68.

18. Patterson DM, Telischi FF, Connell SS, Ulubil SA, Hodges AV, Eshraghi AA et al. Cochlear implantation in organ transplantation. Laryngoscope, 2008; 118(1): 116-19

19. Iverson KC, McKinnon BJ. Cochlear implantation after renal transplantation. Am J Otolaryngol, 2012; 33(1): 150-53.

20. Cortina G, Wiesmayr S, Jungraithmayr T, Roussinow D, Nekahm-Heis D, Zorowka P et al. Successful implantation of a cochlear implant in a four-yr-old boy after kidney transplantation: A case report. Pediatr Transplant, 2009; 13(7): 933-35. 
21. Seri M, Pecci A, Di Bari F, Cusano R, Savino M, Panza E et al. MYH9-related disease: May-Hegglin anomaly, Sebastian syndrome, Fechtner syndrome, and Epstein syndrome are not distinct entities but represent a variable expression of a single illness. Medicine, 2003; 82(3): 203-15.

22. Kohlhase J, Wischermann A, Reichenbach H, Froster U, Engel W. Mutations in the SALL1 putative transcription factor gene cause Townes-Brocks syndrome. Nat Genet, 1998; 18(1): 81-83.

23. Bagshaw SM, George C, Bellomo R. A comparison of the RIFLE and AKIN criteria for acute kidney injury in critically ill patients. Nephrol Dial Transplant, 2008; 23(5): 1569-74.

24. KDIGO Working Group. KDIGO clinical practice guideline for glomerulonephritis. Kidney Inter Suppl, 2012; 2: 139-274.

25. Chertow GM, Burdick E, Honour M, Bonventre JV, Bates DW. Acute kidney injury, mortality, length of stay, and costs in hospitalized patients. J Am Soc Nephrol, 2005; 16(11): 3365-70.

26. Kheterpal S, Tremper KK, Heung M, Rosenberg AL, Englesbe M, Shanks AM et al. Development and validation of an acute kidney injury risk index for patients undergoing general surgery: Results from a national data set. J Am Soc Anesthesiol, 2009; 110(3): 505-15.

27. Loef BG, Epema AH, Smilde TD, Henning RH, Ebels T, Navis $\mathrm{G}$ et al. Immediate postoperative renal function deterioration in cardiac surgical patients predicts in-hospital mortality and long-term survival. J Am Soc Nephrol, 2005; 16(1): 195-200.

28. Basile DP, Anderson MD, Sutton TA. Pathophysiology of acute kidney injury. Compr Physiol, 2012; 2(2): 1303-53.

29. Stacul F, van der Molen AJ, Reimer P, Webb JA, Thomsen HS, Morcos SK et al. Contrast induced nephropathy: Updated ESUR contrast media safety committee guidelines. Eur Radiol, 2011; 21(12): 2527-41.

30. Hoshino A, Enomoto S, Kawahito H, Kurata H, Nakahara Y, Nakamura T. [Prevention of contrast-induced nephropathy using cardiac catheterization combined with hydration, oral $\mathrm{N}$ acetylcysteine, sodium bicarbonate and iso-osmolar contrast agents] J Cardiol, 2007; 50(2): 119-26 [in Japanese]
31. Burden R, Tomson C, Joint Specialty Committee on Renal Disease of the Royal College of Physicians of London and the Renal Association. Identification, management and referral of adults with chronic kidney disease: Concise guidelines. Clin Med, 2005; 5(6): 635-42.

32. London GM, editor. The Clinical Epidemiology of Cardiovascular Diseases in Chronic Kidney Disease: Cardiovascular Disease in Chronic Renal Failure - Pathophysiologic Aspects. Seminars in Dialysis; 2003: Wiley Online Library.

33. Craig R, Hunter J. Recent developments in the perioperative management of adult patients with chronic kidney disease. $\mathrm{Br}$ J Anaesth, 2008; 101(3): 296-310.

34. Dalrymple LS, Go AS. Epidemiology of acute infections among patients with chronic kidney disease. Clin J Am Soc Nephrol, 2008; 3(5): 1487-93.

35. Krishnan M. Preoperative care of patients with kidney disease. Am Fam Physician, 2002; 66(8): 1471-76.

36. Parham WA, Mehdirad AA, Biermann KM, Fredman CS. Hyperkalemia revisited. Tex Heart Inst J, 2006; 33(1): 40-47.

37. Lee TH. Reducing cardiac risk in noncardiac surgery. New Engl J Med, 1999; 341(24): 1838-40.

38. Brienza N, Giglio MT, Marucci M, Fiore T. Does perioperative hemodynamic optimization protect renal function in surgical patients? A meta-analytic study. Crit Care Med, 2009; 37(6): 2079-90.

39. Huerta C, Castellsague J, Varas-Lorenzo C, Rodríguez LAG. Nonsteroidal anti-inflammatory drugs and risk of ARF in the general population. Am J Kidney Dis, 2005; 45(3): 531-39.

40. Munar MY, Singh H. Drug dosing adjustments in patients with chronic kidney disease. Am Fam Physician, 2007; 75(10): 1487-96.

41. Pham PCT, Toscano E, Pham PMT, Pham PAT, Pham SV, Pham PTT. Pain management in patients with chronic kidney disease. NDT Plus, 2009: sfp001.

42. Gardner JS, Blough D, Drinkard CR, Shatin D, Anderson G, Graham D et al. Tramadol and seizures: A surveillance study in a managed care population. Pharmacotherapy, 2000; 20(12): 1423-31.

43. Reichle FM, Conzen PF, Peter K. Nephrotoxicity of halogenated inhalational anaesthetics: fictions and facts. Eur Surg Res, 2002; 34(1-2): 188-95. 